\title{
INTERRELATIONS BETWEEN WINE TOURISM AND GEOTOURISM: A WINE CONSUMPTION SURVEY IN MONOR (HUNGARY)
}

\author{
István BAZSIK \\ Hungarian University of Agriculture and Life Sciences, Econonomic and Regional Doctoral School, e-mail: ibazsik@gmail.com
}

\section{Zoltán BUJDOSÓ*}

Hungarian University of Agriculture and Life Sciences, Institute of Rural

Development and Sustainable Economy, e-mail: Bujdoso.Zoltan@uni-mate.hu

\section{Gábor KONCZ}

Hungarian University of Agriculture and Life Sciences, Institute of Rural

Development and Sustainable Economy, e-mail: Koncz.Gabor@uni-mate.hu

\begin{abstract}
Citation: Bazsik, I., Bujdosó, Z., \& Koncz, G. (2021). INTERRELATIONS BETWEEN WINE TOURISM AND GEOTOURISM: A WINE CONSUMPTION SURVEY IN MONOR (HUNGARY). GeoJournal of Tourism and Geosites, 39(4spl), 1517-1524. https://doi.org/10.30892/gtg.394spl23-796
\end{abstract}

\begin{abstract}
The Danube Wine Region is one of the most important wine regions in Hungary with potential for geological and wine tourism. The research focused on basic issues related to the Monor wine community of the Danube wine region and the Monor cellar village, such as the consumer attitudes of the potential guests of the Monor cellar village and the wine community, the tourist skills and the consumers' knowledge of local products and values. We tried to find answers to our research questions in a complex way with primary questionnaire research and secondary data collection. We found that Monor wine is good, consumer attitudes underpin wine tourism developments. Monor's basic wine tourism skills are good, with valuable elements from a geotourism point of view, but most of the additional tourism services are not available at a satisfactory level.
\end{abstract}

Key words: wine tourism, Monor cellars, wine consumption, landscape value, geosites

$* * * * * *$

\section{INTRODUCTION}

The cellar village of Monor in Hungary dates back hundreds of years. The landscape and field conditions, the landscape values of the cellar village, the spatial structure of the plantations and the diversity of the vine varieties are the outstanding values of the area. Monor has features on the eastern side of Pest County that make it suitable to be a competitive player in wine tourism around Budapest in the long run. From a geotourism point of view, the two geoparks operating in Hungary display the geological values of the mountainous areas. Loess hills, sandy plains, and marshy environments are not currently represented by these parks. Monor is located in a geographical border area that is able to present these geological values in a small area. However, in order to succeed, it is essential to assess Monor, the wine of Monor, the local cellar village, and the geological values of this area, to find its place, role and opportunities.

Monor is an area of Hungarian wine production with a long tradition, which has special features with its small plantations, but also with the system of a cellar village with more than 900 cellars, which can be considered significant on a European scale. In order for this internationally remarkable built value to be maintained, to be a living, prosperous economic factor, it is worth examining such fundamental issues as the consumer and tourist habits and attitudes of potential customers, as well as their knowledge of local products and values. As a modest step, the awareness and recognition of Monor wine and the cellar village and the basic consumer needs were assessed.

\section{LITERATURE REVIEW}

Wine tourism means visiting vineyards, wineries, wine festivals and wine shows, with the primary motivating factor being tasting, consuming and / or learning about the characteristics of the wine region (Macionis, 1996). It is a specific activity organized around interest in wine and wine consumption, which determines the core activity and / or destination itself, through wine consumption and region selection (Hall et al., 2009). This type of tourism, including day trips, is very important for many wine producers because it allows them to sell wine directly to consumers and to help gather customers for sale locally or by mail / courier (Hall et al., 1997). The enjoyable environmental balance of the cultural landscape and the built values also plays an important role in this leisure activity (Hall et al., 2009). The wine tourist is becoming more and more aware of the use of infocommunication tools. In addition to the classical factors, his choice is also significantly influenced by the Internet (Szakály et al., 2018). The tourism literature defines wine tourism as an industry, but points out that other services and goods are inextricably linked to it (Getz, 1998). This category of tourism

\footnotetext{
* Corresponding author
} 
is more typical of rural areas, but can also occur in urban environments. During a wine route, the tourist services are connected in a thematic way, the wine and the grapes provide a framework for the whole journey, it is arranged thematically. The primary goal of wine routes is to introduce grape and wine culture and to promote related services (Szakály et al., 2018). The promotion of wine routes and the enhancement of the reputation of wines have a significant impact on the image of a given wine region and are an integral part of the marketing policy of this area, thus organically helping to achieve the goals set by tourism. Wine tourism is one of the rural development methods that, by acting through the development of tourism in rural areas, can improve the quality of life of those living in wine regions (Csizmadia et al., 2017). Information relevant to Monor's wine tourism is that 429/2020. Government Decree no. designated 11 tourist areas in the country. In the tourist area of Budapest and its surroundings, Monor is not marked in it, against two Pest County wine communities, Etyek is currently stronger in terms of wine tourism, and Neszmély is more significant in terms of its winery are marked. CLVI of 2016 on the state tasks of the development of tourist areas. Taking into account the legal framework of the law, Monor may be at a disadvantage compared to the settlements marked by name in the tourist area.

Geotourism is also a dynamically growing sector that is a special branch of ecotourism (Vancsó et al., 2021). Attractions related to thematic demonstration sites and geoparks typically form the experience factor. Compared to previously known and prosperous sectors, it seeks to attract the attention of those interested in tourism through a new approach. It approaches consumers through geological foundations and natural and built landscape values. The scientific approach of the topic in Hungary mainly, but also internationally, often focuses on the presentation of geotourism attractions, geoparks, and the exploration of potential geopark areas to answer methodological questions (Futó, 2013; Albert et al., 2018; Horváth, 2019; Pál and Albert, 2020; Kelley et al., 2019; Gamkrelidze et al., 2021). International research is already exploring other approaches, such as tourism, social, economic, thematic historical orientation (Farsani et al., 2011, Dowling, 2013, Chen et al., 2020). In addition, we can speak of an approach that examines the environment and geological features, values and their tourist usefulness in their complexity and context (Dowling and Newsome, 2018). There are two UNESCO Global Geoparks in Hungary, which have brought about a positive change in the number of visitors to the affected areas over the last decade (Vancsó et al., 2021). So far, the valuable landscape of our country, which is waiting to be explored in terms of geotourism, has remained unknown, and so has Monor.

These areas are typically not fully protected, although some parts are protected, possibly highly protected, and as a whole have an unique value, but remain unknown in the absence of a well-defined category that ensures integrity (Kiss and Horváth, 2006). The complex value that they typically represent as a geotourism area can be best preserved (Horváth, 2019). In Monor, the natural conditions of wine tourism and geotourism are given, the two types complement each other to provide more information, a more meaningful program and an experience for visitors. For the conceptual definition of geotourism, Dowling and Newsome's formulation of 2018 is certainly remarkable. This has comprehensively, but not very extensively, successfully grasped the traditional essence of the category and extended in parallel with its development.

"The elements of geotourism are geology, tourism, geographical locations, the visits themselves and the transfer of knowledge (Bujdosó et al., 2015). The "geo" part of the term, i.e. geological elements, includes geological features that may be of tourist interest. The word "tourism" refers to the transformation of geological features and properties into tourist resources into "geographical" sights or tours, typically "geosites" in a well-defined area. By combining these elements with other elements of tourism, geological attractions, tours and the transfer of geological information, it is possible to present the "geoheritage" of this particular geological heritage".

The main geological factors are 'form', 'process' and 'time'. These features attract geological tourists. The subject of interest is the landscape, the topographic form, its formation, today's environmental appearance and when, during what geological period, how it was formed (Dowling and Newsome, 2018).

\section{The limitations of the system of origin protection}

The number of Protected Geographical Indications (PGI) adopted by the EU is 6, and the PDO (Protected Designation of Origin) designation has been granted to Hungary for 31. In 2018, Monor acquired the Monor PDO trademark. In Hungary, the protection of origin does not always fulfill its intended function, according to which the given product represents a higher standard and thus a value that can be expressed in money (Popovics, 2009). At the same time, some research points out that GIs allow producers to achieve a premium in theory and in practice (Gál, 2020). The dissonance between the two statements is resolved by the fact that no significant mark-up can be detected for $25-40 \%$ of geographical indications in the middle price range. However, that fact does not raise questions as to the designation of origin but as to the usefulness of using the relevant names. If this intentionally helps sales to low-priced products, as in the case of the DanubeTisza PGI, it can also be positive (Gál, 2020). The basic aim of protection of origin is to increase the income of producers through the use of geographical indications, but this is examined and supported by few "studies with relevant economic data". None of the 111 available value-added studies provide data on whether and to what extent consumers pay higher prices for protected products (Török et al., 2020). The current regulation orients Hungary towards the Latin system, so the wine regions are primarily an administrative unit, but they can also mean territorial units left behind from the Germanic system that preceded the wine reform (Darvasné et al., 2014). This duality is to the detriment of the values of protection of origin, as the demarcation between the wine regions and some of its districts did not take place in an exact way (Gál et al., 2012). It is true not only about wine, but also in general that the situation of the Hungarian system of protection of origin is also reflected in its poor communicability. The relevant research found that consumers have little knowledge about the majority of geographical indications and the categories of protection of origin, they know only the "big names" en masse (eg: salami from Szeged, onions from Makó, wine from Tokaj) (Szakály et. al., 2010). Some research points out that in 
Hungary, in the case of multi-generational, traditionally well-known and long-mentioned products of origin, it can be perceived that consumers attach a significant role to the indicated fact (Popovics et al., 2004). This complex, somewhat eclectic situation is also reflected on the wine side by the communication value pyramid of Hungarian wine created by the Hungarian Tourism Agency, which is based on a unit Tokaji Aszú with a century-old history (Máté, 2019) but it based on wine regions, and in the middle levels of pyramid are territorial definitions, geographical indications are.

\section{Wine consumption in Hungary}

Prior to our primary research on wine tourism, it was important to review the main features of wine consumption in Hungary. The per capita consumption of wine in Hungary seems to be stabilizing after a long-term decline, in 2018 it was 24 liters / person / year (HCSO). According to Gfk's 2016 data, slightly less than 85\% of the active age population consumes wine on some regular basis, so Hungary is still considered a wine-consuming country according to tradition. More than $85 \%$ of purchases are made through retail store chains (Gfk, 2016). In terms of wine tourism and short supply chain producer wine sales, this means that only $15 \%$ of consumption can be considered a potential market. Rosé wine is the most popular among the young, the dry white and red wine are preferred by the older ones (AKI, 2019). According to several surveys (GfK, AKI), customers are particularly price sensitive, and place of origin motivates their decisions (AKI, 2006). The vast majority of Hungarian consumers are looking for 94\% Hungarian wines (Szolnoki et al., 2017). This is followed by the grape variety, the region and the geographical indication in the election ranking. Six-tenths of consumers are looking for wines that can be included in the price category up to HUF 1,000 (approx. $€ 2,8$ ), while only 10\% of them are looking for wines that are more expensive than HUF 5,000 (approx. €14) (Totth and Szolnoki, 2019). According to domestic data, 34\% of the adult population does not consume wine, while $22 \%$ consume it weekly. The latter group consumes $74 \%$ of the total amount of wine (Szolnoki et al., 2017).

\section{MATERIAL AND METHODS}

In order for the local value mentioned in the introduction to be maintained and to be a living, prosperous economic factor, it is necessary to regularly examine such fundamental issues as the consumer and tourist habits and attitudes of potential guests, as well as their knowledge of local products and values. The first, modest step in this study was born.

The research objectives are:

C1. Exploring wine tourism and complementary geotourism values.

C2. Investigation of consumer and tourism habits of potential customers.

C3. Assessing the knowledge of potential customers about local products and values.

C4. Get a picture of the consumer attitudes of potential customers.

Hypotheses:

H1. The reputation of Monor wine is low except for the Monor District.

H2. The quality of Monor wine is good, so they are willing to pay a price similar to the average.

H3. The majority of consumers do not have sufficient knowledge of the PDO mark and its Monorean aspect.

H4. The volume of services complementary to wine tourism is low.

H5. Geotourism values are available to the extent that they help boost tourism at the territorial level of Monor.

Primary and secondary data collection were performed during the study. Primary data were collected with a 20-point questionnaire for the target group of 18-79 year olds, which could be completed online or manually. The size of the collected sample is 505 people. If not recorded as a separate note, then in the case of figures and tables, the sample size, $\mathrm{n}=$ 505 people, is accordingly. The source of the used secondary data at the national level for AKI, KSH, HEGYÍR, HNT and with regard to Monor the Development Concept of Monor Strázsa Hill, various Monor urban spatial impact assessment documents, Monor hydrocarbon concession area complex sensitivity and load test report, Monor municipal environmental protection report program and other professional materials related to the topic. The null hypothesis for both gender and age group is as follows. $\mathrm{H} 0: \mu$ national ratio $=\mu$ sample ratio

The sample is representative of gender and age group, however, on a territorial basis, the Monor District is overrepresented, i.e. $49.1 \%$ of the respondents are local. It was difficult to determine the national average retail price of wine, as the HCSO publishes the wholesale prices of "commercial" 1.5-2 liters and AKI the wholesale prices of goods. In this case, the national average price of producer river wine or bottled wines is the ideal basis for comparison. In the absence of this, I used the average consumer price of bottled wines published in Gfk's 2016 research publication, which was $€ 1.55$, and this was adjusted by the category of "spirits, tobacco products" of the HCSO's consumer price index to calculate the adjusted average price of $€ 1.85$. $€$. Further, where the willingness to pay and the average consumer price were compared, data were examined in relation to the adjusted average price.Monor is a hillside located in Hungary in the Gödöllö-Monor hills, on the south-western border of the Cserhát Mountains, eroded from the Pest alluvial cone plain and the Pilis-Alpár sand ridge geomorphological meadow. The Monor hills are characterized by low ridges divided by erosion valleys. Monor Wine Community is located in the northern part of the Kunság wine region of the Danube wine region (Figure 1).

Its topography is characterized by a low hill between 108 and $229 \mathrm{~m}$, averaging $150 \mathrm{~m}$ above sea level, turning into a sloping plain in the SE direction, protruding into the Great Plain. The highest point of Monor is Strázsa, with its height of 191 $\mathrm{m}$. The water coverage of the area and the proportion of surface watercourses are low, of the former, typically run-off stagnant waters, only Lake Kis still forms a permanent open water surface. The area around Forrás, which was once a swamp area, was declared a protected area of local importance in the mid-1990s, but since then, as the groundwater level has fallen, the area's unique flora has declined significantly. The main component of the soil is Upper Pleistocene loess 10-30 m thick and its sandy subtypes, as well as locally occurring quicksand and bound sand. The crop layer consists of thinly spread rust-brown forest 
soil and carbonate forest residue chernozem soil. They contain large amounts of dolomite, few illite clay minerals, and small amounts of iron and aluminum. This composition is excellent for viticulture. The main shaper of the surface forms seen today was the ice age. During the cooling period, the derivation and then the sand movements shaped the surface. In warmer, humid intervals, erosion shaped the topography. There is a deep sowing line (Vecsés - Monor) on the border of the hills and the Great Plain, in connection with which oil production has boomed in recent years in areas further away from vineyards.

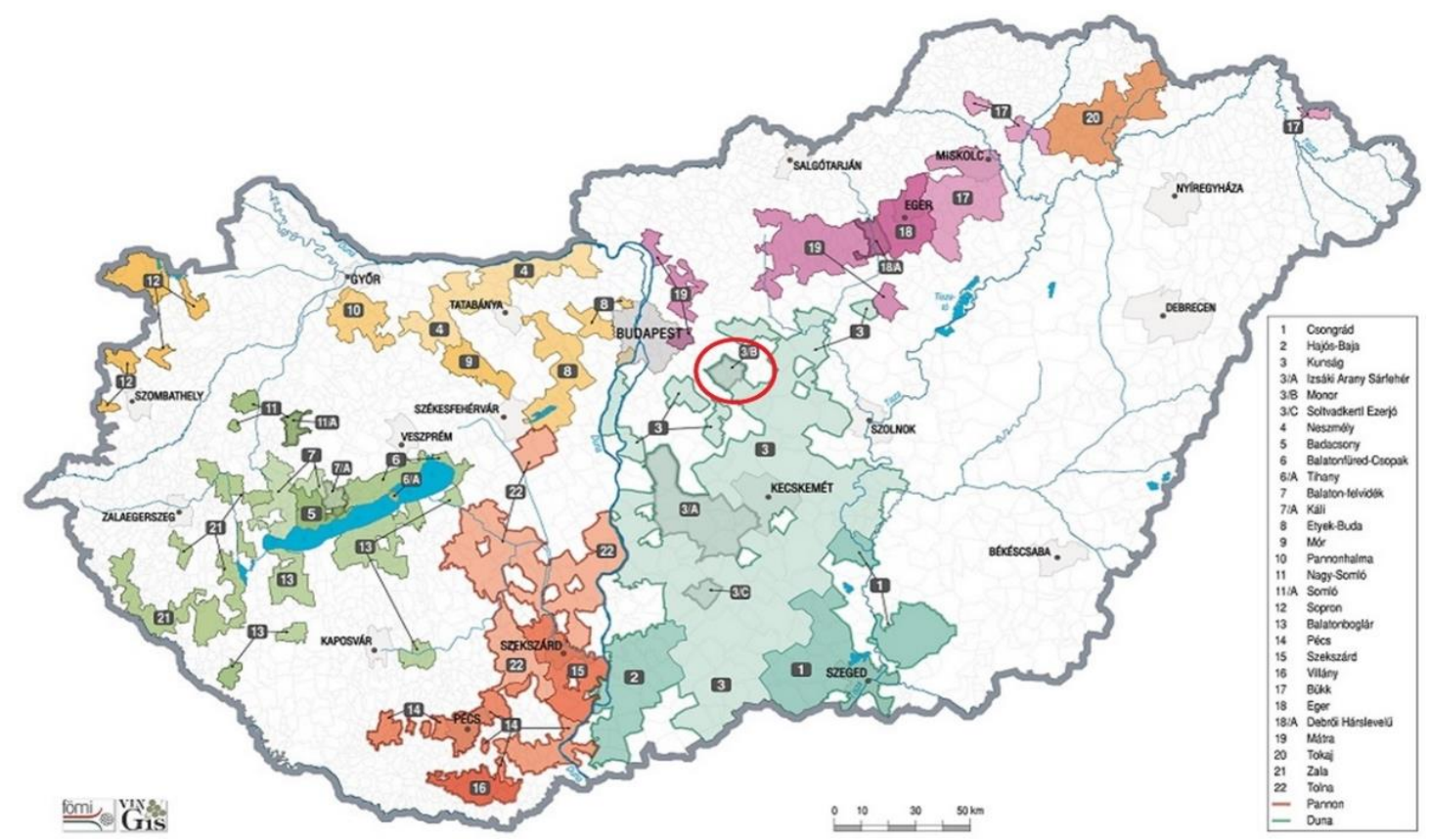

Figure 1. Monor's location in 7 Hungarian wine regions and 22 wine subregions (Source: FÖMI, 2021)

\section{RESULTS}

\section{Development of traditional cellars and viticulture}

In the vicinity of Monor, the main soil former is loess. Although loess is a soft rock, it is able to stand permanently as a vertical wall and the cellars were carved into this rock in Monor (Figure 2). Among the vineyards planted on MonorStrázsahegy were cellars traditionally carved into loess. Among the smaller cellars, there are still a large number of cellars with brick-laid cellar staricase and unbricked cellars. The temperature in the cellars is typically in the optimal range of 10$13{ }^{\circ} \mathrm{C}$, which is ideal for making quality wine. Groundwater is everywhere deeper than 10 meters and its level is constantly decreasing, but there are water layers suitable for irrigation between 40-50 and 90-110 meters. The climatic conditions of the area make the areas around Monor excellent for viticulture.

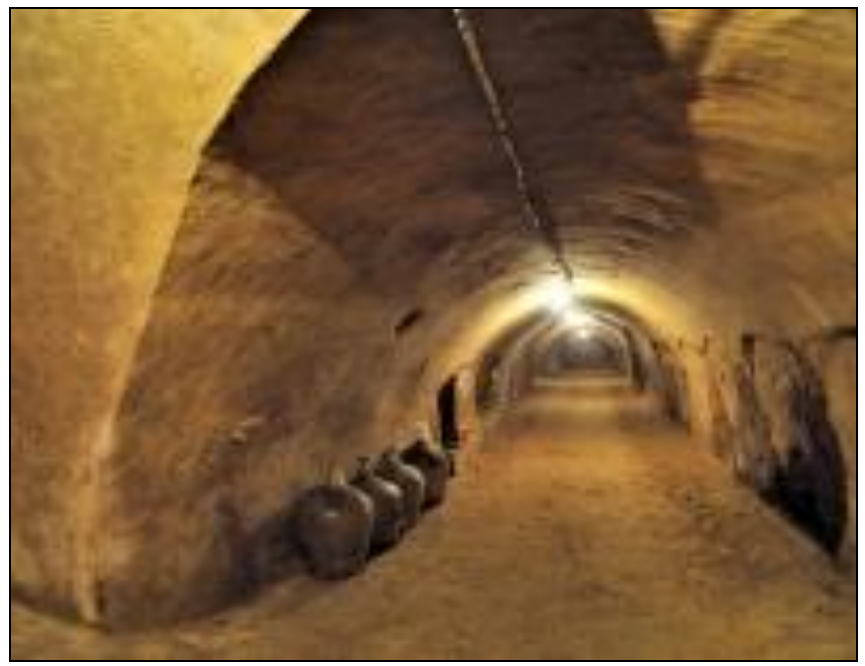

Figure 2. Wine cellar carved into loess

(Source: Own photo, 2021)

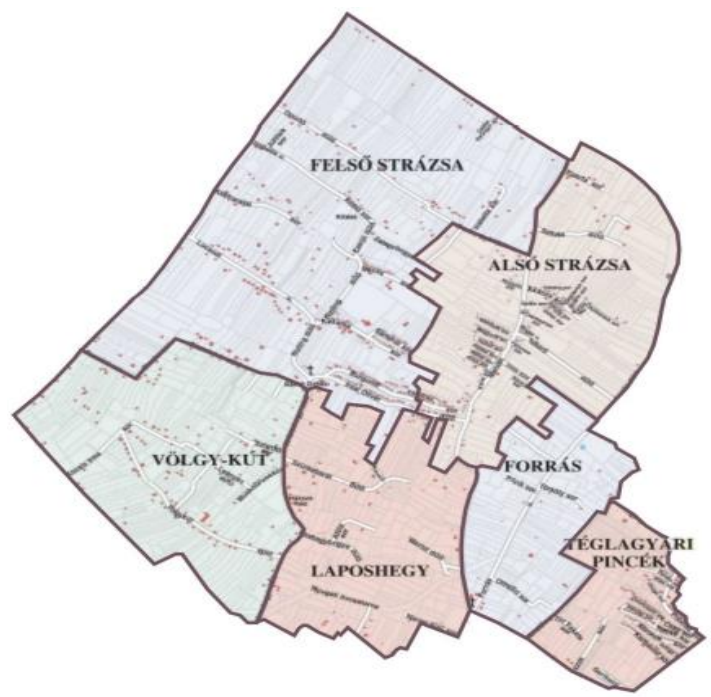

Figure 3. Map of Monor cellar village (Source: Hégely, 2009)

During the construction of the staircases down to cellar, the soil was traditionally excavated and then reburied after the vaulting. A press house was erected in front of most of the cellars, and a series of smaller mounds from the backfilled ground create a characteristic "bakhát" effect on the cellar rows. According to the cellar cadastre closed in 2009, there are 98 architecturally valuable buildings in their original condition and 132 buildings that have been partially remodeled but 
have architectural value (Hégely, 2009). It has also been found that if the original style is restored during the renovation of the buildings and $2 / 3$ of the buildings are renovated in this way, a significant and unique architectural value is created, which ensures a uniform and harmonious image of the area. However, many properties are neglected, in poor and / or ruined condition, but most of them would also be valuable if restored. There are about 960 cellar places and 700 working cellars in the cellar village. The connected and well-navigated cellar village can be divided into five sub-centers: the cellars around Felső-strázsa, Alsó-strázsa, Téglagyári, Vágóhidi and Temető-hegy / Forrás (Figure 3). In terms of spatial structure, with the exception of the latter, the characteristic rows of cellars with a bakhát part of the cellar built closely together are the dominant landscape elements. In the case of the cemetery hill / Forrás, the independent cellars next to the small plantations of $800 / 1200 \mathrm{~m}^{2}$ are typical. Rows of cellars separated from the vineyards form the basis of wine tourism, where cozy community events take place. Garden-friendly farming takes place in cellars with vineyards.

The first cellars of the cellar village of Monor were hole cellars carved into the loess wall, of which the loess road on Acsády út stands for nowadays. These centuries-old structures are of historical significance. This is followed by a cellar that protrudes from the ground and a deep cellar that can be locked by a door built into its brick wall. Then, in front of the gáderstaircase down to cellar, a low, hut-like structure was placed, with a saddle roof perpendicular to the street front. The next type of press house already represents house-like constructions, in which you can walk narrowly but already upright. The press houses built after that already take on the character of farmhouses in the Great Plain. Perpendicular to the gable roof street, the front wall is gabled. The fourth type can be considered as an improvement on the previous type. Here, as an extension of the roof, a covered foyer was built, held by columns. The last two building types evoke the middle-classness houses of the 19th century, with a saddle roof parallel to the street front. There are also two small windows next to the entrance (Gajdos, 1995). In addition to the common style features, the last type of building differs from the previous one in the colonnade porch created by the widening of the roof (Figure 4).

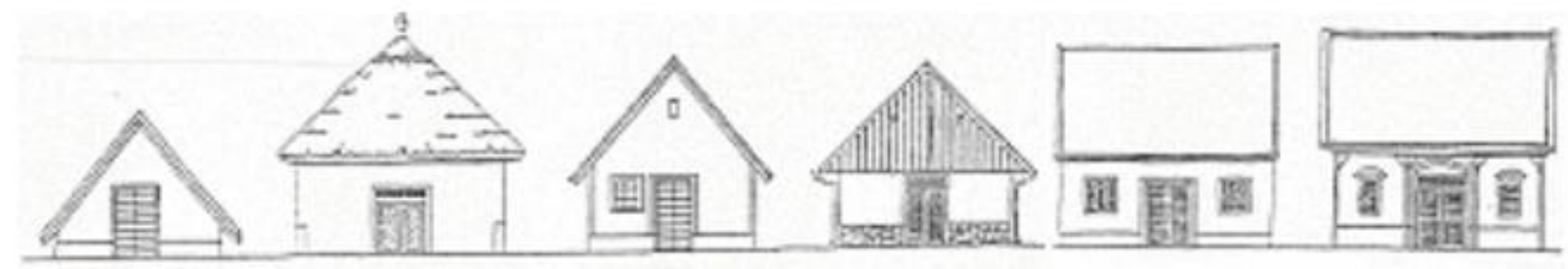

Figure 4. Typical architectures of Monor wine cellars (Source: Gajdos, 1995)

For the cellars, which have mostly survived in their original state, three core areas have been demarcated.

- Kadarka, Mud White line,

- Irsai Olivér vineyard, Burgundy and Künkinka line,

- Apples, Pears, Raspberries, Dirt, Currants, Hazelnuts, Almonds, Pine Row, Cherry Vineyard.

There are several unique built and natural landscapes in and around the cellar village of Monor. These:

- Statues of St. Orban; Crucifixes,

- The first cellars carved into a loess wall more than 200 years old,

- Wheeled wells in need of renovation,

- Lookout tower, (provides a visibility of almost $50 \mathrm{~km}$, mainly to the west)

- Thousand Cellars Viticulture and Oenology Study Trail,

- A multitude of geological forms formed during the glacial period, eg loess deep roads.

- Quicksand formations,

- Vecsés-Monor sower and the oil extraction observed along it,

- The geological diversity resulting from the confluence of the Great Plain and the Gödöllö-Monor hills,

- Extensive cellar village system with a special spatial structure .

- In the Source area there is an untouched sand oak area in a locally protected area.

Taking into account the environmental conditions and landscape values, the area can be considered valuable from both a wine tourism and geotourism point of view. Other important landscape values of geological significance can be found in the $20 \mathrm{~km}$ radius of the studied area:

- Ex Lege areas located in the Tápió Nature Park (12 bogs, 17 saline lakes, 8 kunhalom, 9 earthworks and dozens of springs),

- Svévharaszt, sand juniper, b uckás forest and sand steppe,

- Alberti loess wall and bee,

- Pannonian loess grassland in good condition, Pannonian sand grassland,

- Blue-swamp marshes on calcareous, peat and clay soils,

- Lake Gombai, (dam reservoir).

The local geotourism values are not professionally assessed, there is no such vault. The charming loess deep roads created over hundreds of years, the cellars carved into the loess, the vantage points of the hilly areas with a visibility of up to $50 \mathrm{~km}$, the sandy habitats and the swampy wetlands are all present, but their tourist attraction has has not known enough by local professionals For Monor and its surroundings on the geopark development of even raised long-term goal, but the Monor cellar village of Vecsés Monor seed oil production taking place along Located in the Csévharaszt ősborókás and Tapio nature park geology and landscape values, overall, a color, each well additional attractions they provide a mass that can also represent the geological and natural diversity of sandy plains, loess hills, and wetland wetlands. 


\section{Knowledge of the cellar village and events}

"Is there a wine community and/or cellar village in Monor?" and "How many wine cellars do you think Monor has?" questions We try to explore to what extent these local values are known. It can be stated that outside the Monor District, it is not known that Monor has one of the largest cellar villages in Europe with one of the largest territory cellar villages in Europe, with almost the largest quantity of cellars (950). 280 of the respondents answered the question "how satisfied were you with attending a wine event in Monor". 65.7\% of the respondents rated the event at a level of 8 or higher, with a weighted average rating of 7.51 (Figure 5). According to this, the organized events provide quality recreation for those interested. This provides an excellent basis for furthering tourism developments. Based on the above, it is expedient to convert and use the local values outstanding from the point of view of wine tourism into information.

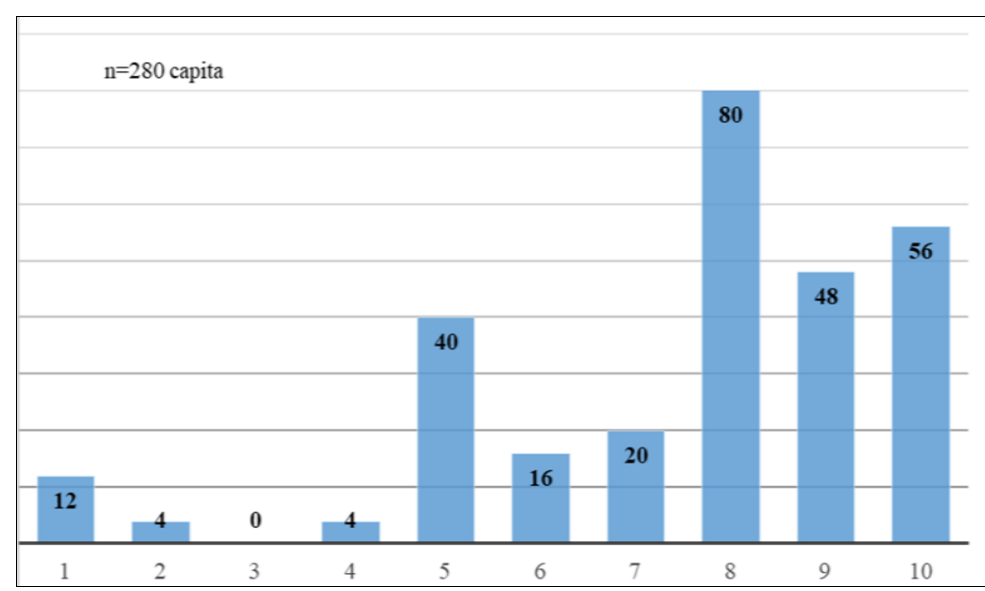

Figure 5. If you participated in a Monor wine event,

how much did you enjoy it? (10 Likert scale, number of respondents)

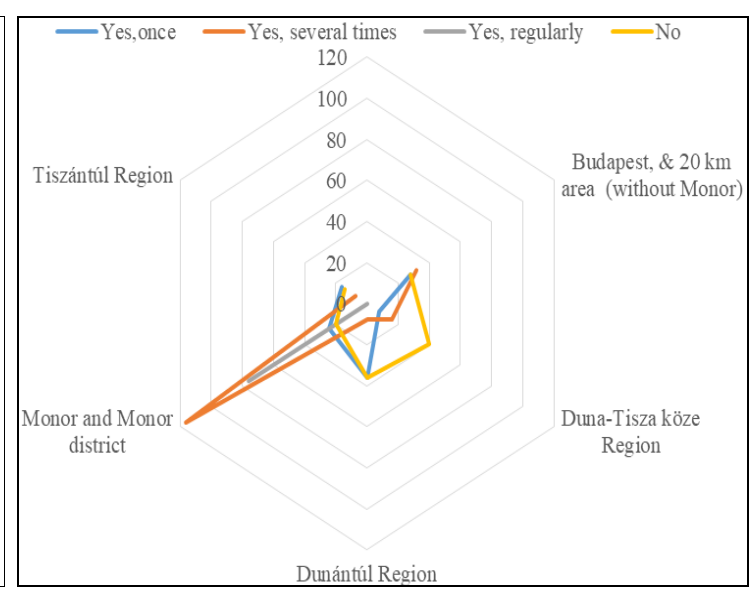

Figure 6. Have you ever consumed Monor wine? (number of respondent)

\section{Knowledge of Monor wine}

The regular consumer of Monor wine (76 people) is exclusively in the Monor District, which accounts for 32.2\% of local respondents. This highlights the fact that without short supply chain sales, local production would not exist, so the needs of the "patriotic" population should be treated as a priority. Examining the totality of consumers, with the exception of the Monor District, the distribution of yes answers exceeded the negative ones significantly only in Budapest. In Monor, $91.5 \%$ of the respondents, while $68.1 \%$ in Budapest and the surrounding area, answered yes. Regarding the consumption habits related to Monor wine, it should be emphasized that the local consumer base is very strong (Figure 6), and in the case of Budapest and its surroundings, the consumer information of wine can be a good basis for recruiting regular consumers and wine tourists, so it is worth focusing on expansion. In the case of one-off consumers, the regional figures indicate that domestic consumers have already encountered Monor wine, but this is not enough to consume it recurrently, so building a national consumer base is currently not a realistic goal.

\section{Quality of Monor wine and wilingness to pay}

Nearly $53 \%$ of respondents rated Monor wine as good, another $24.5 \%$ rated it as medium and less than $8 \%$ as excellent. Based on this, $85 \%$ of the respondents, in addition to the rating according to their individual taste, do not have any serious reservations about Monor wine, they mostly rate it as good. This is an excellent base for organizing "wine" tourism events. $33.1 \%$ of respondents would give a price of between $€ 1.4$ and $€ 2.79$ for a bottle of wine, and almost $40 \%$ would not regret it for more than that, ie $€ 2.8-3.59$ (Table 1). For a similar question to river wine, more than half of the answers rated their willingness to pay between $€ 1.4-2.79$ per liter of wine. So the majority of respondents would pay more for bottled wine in Monor than the adjusted average price, so this also strengthens the emphasis on wine as a pull product for tourism.

Table 1. How much would you give for a bottle $(0.751)$ of Monor wine (in $€)$

\begin{tabular}{|c|c|c|c|}
\hline Answers & Capita & Distribution\% & Cumulated\% \\
\hline Less than 1.39 & 24 & 4.8 & 4.8 \\
\hline between 1.4-2.79 & 167 & 33.1 & 37.9 \\
\hline between 2.8-3.59 & 200 & 39.6 & 77.5 \\
\hline between 3.6-3.99 & 64 & 12.7 & 90.2 \\
\hline More than 4.00 & 8 & 1.6 & 91.8 \\
\hline I wouldn't pay & 30 & 5.9 & 97.7 \\
\hline No answer & 12 & 2.4 & 100 \\
\hline Sum & 505 & 100 & \\
\hline
\end{tabular}

The reputation of PDO (protected designations of origin) in local and country

$72.7 \%$ of the respondents had consumed Monor wine
Table 2. Do you know what means PDO (in Hungarian OEM)?

\begin{tabular}{|l|c|c|c|}
\hline \multicolumn{1}{|c|}{ Answers } & capita & Distribution\% & Cumulated\% \\
\hline Protected Designations of Origin & 236 & 46.7 & 46.7 \\
\hline Protected Original Quality & 64 & 12.7 & 59.4 \\
\hline Nationally Recognized Sample & 4 & 0.8 & 60.2 \\
\hline Nationally Recognized Quality & 32 & 6.3 & 66.5 \\
\hline Don't know & 169 & 33.5 & 100 \\
\hline Sum & 505 & 100 & \\
\hline
\end{tabular}

Table 3. Is there Monor PDO wine?

\begin{tabular}{|l|c|c|c|}
\hline \multicolumn{1}{|c|}{ Answers } & capita & Distribution\% & Cumulated\% \\
\hline Yes & 184 & 36.4 & 36.4 \\
\hline No & 12 & 2.4 & 38.8 \\
\hline Don't know & 309 & 61.2 & 100 \\
\hline Sum & 505 & 100 & \\
\hline
\end{tabular}


at least once, and $50.4 \%$ had done so several times or regularly, so it can be assumed that the majority have some basic knowledge of local wine. Consequently, it is worth examining consumers' knowledge of the Monor PDO label, which is acquired by producers primarily for marketing and at a significant investment of money, and of the general content of the label.

PDO marking gave an indication that they thought they knew the correct answer, but several of them still did not answer correctly, so less than half of the total sample, i.e. 46.7\%, could mark an accurate and correct answer (Table 2). Based on this, although PDO certification is familiar to people, they are limited in its content.

The Monor PDO was recognized by the European Commission in 2018, so it is considered young. The designation of origin was justified, according to the Monor PDO product specification, in the case of the wines produced here, nor can they be reproduced in other wine regions. This typicality is manifested primarily in taste- and flavor-rich, low-acidity, alcohol-rich wines. Due to their soil properties, the wines have a higher mineral content and mineral characteristics. " The cited features are outstanding product characteristics, if known, the consumer can pair a quality surplus with the product, which typically also motivates the willingness to pay. But does the consumer know that there is such an PDO mark? (Table 3).

Of the respondents, only 36.4\% knew they had a Monor PDO. Based on the data of the cross-sectional table, it can be stated that the awareness of the origin marker is high in the Monor District, here $52.5 \%$ of the respondents knew the correct answer. Only $10.8 \%$ of the Trans-Tisza people had the right information, about $18 \%$ of the people of Budapest and its surroundings and the Danube-Tisza, and about 35\% of the Transdanubians knew the existence of the Monor PDO mark. Thus, the Monor PDO was known to the majority of respondents in the Monor District, to a different extent, but significantly less, in the other regions. Thus, at present, the Monor PDO is not clearly considered to be a factor attracting wine tourism.

\section{Tourism skills}

Budapest is located approximately $40 \mathrm{~km}$ away, which is a significant potential base for day trips by both domestic and foreign guests, however, the number of group excursions organized here is currently negligible. Although local accommodation has grown by around $16 \%$ in the last ten years, the city can still show a capacity of only 150 people, of which 78 are maintained by the $* * *$ + rated Nyerges Hotel, which is at the top of the local service ranking. Thus, long weekends and multi-day vacations cannot be a large consumer base either. The number of catering units is 75 , they also provide a significant number of hot kitchen services, in recent years several high-quality catering establishments have opened in the city (la Via, Vejkó, Kult), so there is no major lag in this area. Producer wine surveying was not addressed locally before 2019, and since then 3 service providers of this type have opened their doors.

There is currently no cellar open in full-time system on Strázsa Hill, 12 cellars are open on weekends, and a similar number of service providers accept guests by telephone. Some of them also provide hot kitchen service. Tourism development is significantly hampered by the fact that, despite the huge number of cellars, there is no cellar that is open continuously or seasonally. On-call weekend reception is extremely poor. The lack of care is not enticing to visitors, as the guest does not receive positive confirmation or provide a level of experience factor that can be conveyed by the visitor that could attract the attention of others (it is not posted on the tourist's page facebook, twitter post). There are no additional services such as traditional activities, handicrafts, fair sweets in and around the cellar village. This is also a significant shortcoming, as the trinkets that can be bought and / or made here could also strengthen the attachment of the guests, increase the experience factor and make the memories of the trip tangible at home.

\section{CONCLUSIONS}

From the point of view of wine tourism, the conversion and use of outstanding local values into information is essential. It is proposed to display the cellar village of Monor, which is a significant built and natural value at the European level with nearly a thousand cellars, as a main marketing element with an independent slogan and an intensive marketing campaign. Based on the scale evaluation of the participants in the wine events, the quality of the current programs and the satisfaction of the visitors are high (average 7.51 on a ten-point scale). Thus, it is useful to maintain the events and their quality in the future. The local consumer base of Monor wine is strong, it is worth keeping it, the proximity of the Budapest market, and based on consumer attitudes, the possible market expansion in this direction is worth doing. Monor producers currently have a chance to stay in the market with short supply chain sales. Wine tourism is essential for the development of this commercial segment, so wine tourism services need to be expanded. Consumers rate Monor wine as good, and are willing to pay a much higher price for bottled wines than the national average and current wines. This is a positive feedback on the product, which confirms that Monor Wine as a product serves as a good basis for wine tourism.

In Monor, the tourism, craft and catering services supporting wine tourism are generally not available in sufficient quantities. The establishment of an open-air visitor center center zone and its initial municipal operation or support can significantly improve the standard on the relevant topic. Monor has a complex geographical and environmental value mass, which makes it possible to make the settlement and the cellar village attractive from a geotouristic approach.

Given Monor's PDO awareness and recognition, brand building ideas for PDO certification need to be reviewed. It is recommended to treat PDO certification as a secondary brand building factor. The value of Monor PDOs can be created primarily in professional circles with gold, silver and certifications achieved at major professional wine competitions, and this can also establish the subconscious relationship of equal high quality Monor wine in the public consciousness.

\section{REFERENCES}

Albert, G., Pál, M., \& Shwarcz, Gy. (2018). Csopak és környéke geotúratérképe. [Geotour map of Csopak \& it's vicinity.] Schwarcz

Térkép, Tök, (in Hungarian). 
Bujdosó, Z., Dávid, L., Wéber, Z., \& Tenk, A. (2015). Utilization of Geoheritage in Tourism Development. Procedia - Social And Behavioral Sciences, 188, 316-324. https://doi.org/10.1016/j.sbspro.2015.03.400

Chen, A., Ng, Y., Zhang, E., \& Tian, M. (2020). Dictionary of Geotourism. Science Press Beijing, Springer. https://doi.org/10.1007/978981-13-2538-0

Csizmadia, L., Erdősi, M., \& Szabó, G. (2012). Borturizmus - Bormarketing: Gyakorlati ismeretek. [Wine marketing: Pracitcal Knowledge.] Magyar Borutak Kft., Kecskemét, (in Hungarian).

Darvasné Ördög, E., Székelyhidi, K., Felkai, B.O., \& Szabó, D. (2014). Európai Uniós és a nemzeti élelmiszer-minöségrendszerek és védjegyek helyzete Magyarországon. [The situation of Eu \& national food-quality systems \& trade-marks in Hungary.] AKI, 161 p. (in Hungarian). http://repo.aki.gov.hu/63/1/ak_2014_04_Min\%C5\%91s\%C3\%A9grendszerek.pdf

Dowling, R. (2013). Global Geotourism - An Emerging Form of Sustainable Tourism . Czech Journal of Tourism, 2 (2), 59-79. https://doi.org/10.2478/cjot-2013-0004

Dowling, R., \& Newsome, D. (2018). Handbook of Geotourism. Edward Elgar Publishing, Cheltenham, UK, Northampton, USA.

Farsani, N. T., Coelho, C., \& Costa, C. (2011). Geotourism and geoparks as novel strategies for socio-economic development in rural areas. International Journal of Tourism Research, 13 (1), 68-81. https://doi.org/10.1002/jtr.800

Futó, J. (2013). Túrajavaslatok - A természet élménye a Balaton mellékén és a Bakonyban. [Hiking suggestions - Experience nature along Lake Balaton and in the Bakony.] Balatonfelvidéki Nemzeti Park Igazgatóság, Csopak, (in Hungarian).

Gajdos, I. (1995). Tanulmány a monori pincesorok megújitásáról és rendezéséröl. [Study on the renewal and management of the cellar rows in Monor.] A.D.U. Építész Iroda Kft, (in Hungarian).

Gamkrelidze, I., Okrostsvaridze, A., Koiava, K., \& Maisadze, F. (2021). Geotourism potential of Georgia, the Caucasus. Springer, Cham, Switzerland, ISBN: 978-3-030-62966-3.

Gál, P. (2020). A borárakat meghatározó tényezök Magyarországon, különös tekintettel a földrajzi árujelzökre. [Determinant factors of the wine prices, in particular geographical indicators.] $\mathrm{PhD}$ dissertation, Corvinus University of Budapest, 245 p. (in Hungarian).

Gál, P., \& Kiss, A. (2012). Élelmiszerbiztonság, ellenörzés, eredetvédelem. [Food-quality, controll, origin protection] Károly Eszterházy College, Eger, (in Hungarian).

Getz, D. (1998). Wine tourism: Global overview and perspectives on its development. In: Dowling, R., and Carlsen, J. (Eds), Wine Tourism-Perfect Partners, Proceedings of the First Australian Wine Tourism Conference. Canberra: Bureau of Tourism Research.

Hall, C.M., \& Johnson, G. (1997). Wine Tourism in New Zealand:Larger Bottles or Better Relationships? Center for Tourism, University of Otago, Dunedin.

Hall, C.M., Sharples, L., Campbourne, B., \& Macionis, N. (2009). Wine Tourism Around the World. Routledge, 368 pp. https://doi.org/10.4324/9780080521145

Hégely, P. (2009). Monori Strázsahegyi Fejlesztési Koncepció. [Monor Strázsa Hill Development Concept, (in Hungarian).

Horváth, G. (2019). A földrajzi ismeretek terjesztésének új színterei: a geoparkok.. [New plenums for the dissemination of geographical knowledge: geoparks.] GeoMetodika 3 (3),19-27, (in Hungarian). https://doi.org/10.26888/GEOMET.2019.3.3.2

Kelley, D., Page, K., Quiroga, D., \& Herrera, R. (2019). In the Footsteps of Darwin: Geoheritage, Geotourism and Conservation in the Galapagos Islands. Springer, Cham, Switzerland. https://doi.org/10.1007/978-3-030-05915-6

Kiss, G., \& Horváth, G. (2006). A földtudományi értékek megörzésének új eszközei: a geoparkok. [ New tools for preserving earth science values: geoparks.]. In Kókai S. (ed.), Geography and Tourism, Nyíregyháza, 163-171, (in Hungarian)

Macionis, N. (1996). Wine Tourism in Australia: A Case Study of the Canberra Cool-Climate Wine Region. University of Canberra.

Máté, A. (2019). Bormarketing, Borkereskedelem. [Wine marketing: wine trade.] PTE KPVK, Szekszárd, (in Hungarian).

Pál, M., \& Albert, G. (2020). Csopak és környékének geoturisztikai felmérése. [Geotouristic survey of Csopak \& it's vicinity.] Földrajzi Közlemények 144 (2), 153-170. (in Hungarian).https://doi.org/10.32643/fk.144.2.2

Popovics, A. (2009). A földrajzi helyhez kapcsolódó és a hagyományos magyar termékek lehetséges szerepe az élelmiszerfogyasztói magatartásban. [ The Possible Role of geographical place connected and traditional Hungarian food products in consumer behavior.] Doctoral (PhD) dissertation, Gödöllö, (in Hungarian).

Popovics, A., \& Pallóné Kisérdi, I. (2004). A hagyományos magyar élelmiszerek ismertsége a fogyasztók körében. [Knowledge of Traditional Hungarian foods among consumers] Élelmiszervizsgálati Közlemények 50, 28-36, (in Hungarian).

Szakály, Z., Pallóné Kisérdi, I., \& Nábrádi, A. (2010). Marketing a hagyományos és táijellegü élelmiszerek piacán. [Marketing on the market of traditional \& provincial foods] Kaposvár, ISBN 978-963-9821-14-9, (in Hungarian).

Szolnoki, G., \& Totth, G. (2017). A magyar borpiac és a borfogyasztói szokások elemzése. [Analysis of Hungarian wine market \& wine consumption habits] (HNT, professional presentation, in Hungarian)

Totth, G., \& Szolnoki, G. (2019). A magyarországi borfogyasztói szokások és a borpiac elemzése. [Analysis of wine consumption habits \& wine market of Hungary] Management 63 (1), 22-3, (in Hungarian). https://doi.org/10.22004/ag.econ.284793

Török, Á., \& Maró, Z.M. (2020). A földrajzi árujelzök gazdaságtana - az empirikus bizonyítékok. [ The Economics of Geographical Indications - Empirical Evidences.] Közgazdasági Szemle 67 (3), 263-288, (in Hungarian). https://doi.org/10.18414/KSZ.2020.3.263

Vancsó, J., Nagy, M., \& Bazsó, T. (2021). The role of geoparks in geotourism and with special regard to the domestic situation. Tourism Bulletin 21 (1), 34-43. https://doi.org/10.14267/TURBULL.2021v21n1.4

*** AKI (2019). Agrárpiaci jelentések - Zöldség, gyümölcs és bor [Agricultural Market Reports - Vegetables, Fruits and Wine] 23 (5) (in Hungarian).

*** AKI (2006). A borpiac helyzete és kilátásai. [Wine market's postion \& perspectives]. (in Hungarian). http://repo.aki.gov. hu/2912/1/at_2006_06.pdf

*** Gfk (2016). Sajtóközlemény, [Press release]. September 14, 2016, (in Hungarian).

*** FÖMI (2021): VINGIS - Magyarország térinformatikai szőlőültetvény regisztere. [VINGIS - Geographic Information System supported Vineyard Register in Hungary.] vingis.hu

Article history: Received: 25.07.2021 Revised: 16.12.2021 Accepted: 22.12.2021 Available online: 31.12 .2021 